\title{
Androgen insensitivity syndrome
}

INSERM

\section{Source}

INSERM. (1999). Orphanet: an online rare disease and orphan drug data base. Androgen insensitivity syndrome. ORPHA:754

Androgen insensitivity syndrome (AIS) is a disorder of sex development (DSD)

characterized by the presence of female external genitalia, ambiguous genitalia or variable defects in virilization in a $46, X Y$ individual with absent or partial responsiveness to age-appropriate levels of androgens. It comprises two clinical subgroups: complete AIS (CAIS) and partial AIS (PAIS) (see these terms). 